\title{
GAMBARAN TINDAKAN PENCEGAHAN PENULARAN COVID-19 PADA PASIEN HEMODIALISIS DI RSUD ARIFIN ACHMAD PROVINSI RIAU
}

\author{
Dini Haryati Ulfa ${ }^{1)}$, Bayhakki' ${ }^{2)}$, Hellena Deli ${ }^{3)}$ \\ ${ }^{1,2,3}$ Fakultas Keperawatan, Universitas Riau \\ Email: dini.haryati6601@student.unri.ac.id
}

Diterima: November 2021, Diterbitkan: Desember 2021

\begin{abstract}
Abstrak
Corona virus disease 2019 (Covid-19) merupakan penyakit menular yang menginfeksi saluran pernapasan. Covid-19. Pasien penyakit ginjal kronik yang menjalani hemodialisis beresiko tinggi untuk terkena infeksi virus sehingga pasien hemodialisis harus melakukan tindakan pencegahan setiap hari. Penelitian ini bertujuan untuk mengetahui gambaran tindakan pencegahan penulran covid-19 pada pasien hemodialisis di RSUD Arifin Achmad Provinsi Riau. Desain penelitian yang digunakan adalah uji statistik deskriptif dengan jenis penelitian kuantitatif. Metode pengambilan sampel yang digunakan yaitu metode Consecutive Sampling. Jumlah sampel sebanyak 43 responden sesuai kriteria inklusi yaitu bersedia menjadi responden dan pasien yang menjalani hemodialisis, instrument yang digunakan menggunakan format observasi. Hasil penelitian menunjukan mayoritas responden penelitian berusia 56-65 tahun sebanyak 46,5\%, berjenis kelamin laki-laki sebanyak $60,5 \%$ dan berpendidikan terakhir SMA sebanyak 37,2\%. Hasil tindakan pencegahan penularan covid-19 pada pasien hemodialisis dalam kategori "Baik" sebanyak 62,8\%. Tindakan pencegahan penularan yang baik dan benar dapat membantu menurunkan angka penularan covid-19 pada pasien hemodialisis maka dari itu diharapkan pasien hemodialisis dan keluarga tetap mempertahankan tindakan pencegahan penularan Covid-19 sesuai protokol kesehatan
\end{abstract}

Kata Kunci: Tindakan pencegahan, Covid-19, Hemodialisis

\begin{abstract}
Corona Corona virus disease 2019 (Covid-19) is an infectious disease that infects the respiratory tract. Patients chronic kidney disease who undergoing hemodialysis are high risk of infections, patients who undergoing hemodialysis must take preventive every day. This study aims to Describe actions to prevent transmission of covid-19 in hemodialysis patients at Arifin Achmad Hospital, Riau Province. The research design used is descriptive statistical test with quantitative research type. The sampling method used is the Consecutive Sampling method. The samples is 43 respondents according to the inclusion criteria, willing to be respondents and patients undergoing hemodialysis, the instrument used used an observation form. The results showed the majority of research respondents aged 56-65 years as much as 46.5\%, male gender as much as $60.5 \%$ and high school education as much as $37.2 \%$. The results of actions to prevent the transmission of covid-19 in hemodialysis patients in the "Good" category were $62.8 \%$. Good or correct transmission prevention actions can help reduce the transmission rate of Covid-19 in hemodialysis patients, therefore it is hoped that hemodialysis patients and their families keep up prevention actions for Covid-19 transmission according to health protocols.
\end{abstract}

Keywords: Preventive actions, Covid-19, Hemodialysis

\section{PENDAHULUAN}

Corona Virus Disease (Covid19) ialah bagian dari keluarga virus yang memunculkan penyakit dengan gejala ringan hingga berat. Paling tidak ada dua

jenis virus corona yang diyakini menyebabkan gejala yang parah, misalnya Middle East Respiratory Syndrome (MERS-CoV) dan Severe Acute 
Respiratory Syndrome (SARS-CoV). Novel corona virus (2019-nCoV) ialah varian virus yang baru dimana tidak teridentifikasi dalam tubuh manusia. Coronavirus ialah penyakit zoonosis (menular antara hewan dan manusia). Studi menunjukkan bahwa SARSCoV ditularkan dari kucing luwak (civet cats) kepada manusia, dan MERSCoV penulurannya dari unta ke manusia. Virusvirus corona yang diketahui menginfeksi hewan, tetapi belum ada bukti dapat menularkan kepada manusia. Pada tanggal 31 Desember 2019, Kantor WHO China membuat laporan kasus pneumonia yang tidak ditemukan penyebab munculnya di Kota Wuhan, Provinsi Hubei, China. Pada 7 Januari 2020, China melakukan identifikasi pneumonia yang tidak dapat dijelaskan penyebabnya itu menjadi jenis virus corona baru (Novel Coronavirus, 2019nCoV). Peningkatan pasien kasus nCoV pada tahun 2019 ini terbilang pesat dan menyebar di luar daerah Wuhan dan negara lainnya. Hingga 26 Januari 2020, terdapat 1.320 kasus terkonfirmasi di 10 negara di dunia dengan 41 kematian. CFR $3,1 \%$. WHO menyatakan bahwa penularan terbatas dari manusia ke manusia sudah diidentifikasi di Wuhan, Cina dan mayoritas negara-negara lain (Fathiyah, 2020).

Menurut data hingga tanggal 2 Maret 2020, jumlah kematian di dunia mencapai 2,3\% dan khususnya di kota Wuhan ialah 4,9\%, serta di provinsi Hubei $3,1 \%$. Angka di provinsi lainnya di Tiongkok ialah $0,16 \%$. Berdasar pada penelitian terhadap 41 penderita awal di Wuhan ada 6 orang mengalami kematian (5 orang di ICU dan 1 orang non-ICU) (Huang, 2020). Kasus orang meningggal paling banyak terjadi pada lansia dan memiliki penyakit bawaan. Kasus orang meninggal pertama pasien laki-laki berumur 61 tahun dengan penyakit bawaan tumor intraabdomen dan liver yang memiliki kelainan (Yuliana, 2020).

Menurut World Health

Organization (WHO, 2020) Saat ini pada tanggal 16 Agustus 2020 sudah ada 176 negara yang terjangkit transmisi lokal, diantaranya ialah Indonesia dengan jumlah 2,345 kasus terkonfirmasi dan 50 jiwa meninggal. Sementara di Provinsi Riau untuk saat ini pada tanggal 28 Agustus 2020 sudah ada 1.460 jiwa terkomfirmasi, 873 jiwa sembuh dan 25 jiwa meninggal, dan daerah Pekanbaru pada tanggal 28 Agustus 2020 sudah ada 542 jiwa positif Covid-19 dan 9 jiwa meninggal dan akan terus bertambah (Corona Riau, 2020).

Covid-19 lebih menyerang pasien yang lebih tua tetapi tidak menutup kemungkinan pasien remaja atau anak kecil, dan pasien yang memiliki riwayat penyakit penyerta seperti pasien yang berpenyakit ginjal atau kondisi kesehatan yang parah diyakini memiliki risiko lebih tinggi terhadap COVID-19 dengan lebih serius. Menurut Kemenkes (2020) di Dunia kesehatan, penyakit bawaan memanglah jadi sesuatu yang membuat takut masyarakat sebab bisa mempengaruhi kesehatan pasien yang terpapar Covid-19. Penyakit penyerta ialah satu diantara kelompok yang paling rentan terkena virus, penyakit penyerta yang terkonfirmasi adalah penyakit hipertensi, diabetes, jantung dan gagal ginjal, penyakit ginjal atau gagal ginjal juga bisa membuat parah kondisi penderita Covid19. Menurut Liana (2015) pasien Hemodialisis memiliki resiko tinggi untuk terkena infeksi apabila dibanding dengan penderita non-hemodialisis baik dengan langsung ataupun tidak langsung pada benda yang terkena kontaminasi, atau dengan perantara tangan petugas.

Menurut Nuari (2017) Chronic Kidney Disease (CKD) atau Penyakit Ginjal Kronik ialah masalah fungsi renal yang progresif dan irreversibel yang mana daya tubuh mengalami kegagalan dalam mempertahankan metabolisme dan menyeimbangkan larutan elektrolit, menimbulkan uremia (retensi urea dan sisa nitrogen lainnya dalam darah). Pada mulanya, penyakit gagal ginjal kronik tidak menyebabkan gejala dan tanda, 
bahkan sampai proses penyaringan glomerulus yang besarnya $60 \%$, penderita masih asimtomatik tetapi telah mengalami penambahan jumlah urea dan kreatinin serum. Penyakit ginjal kronis bisa dipengaruhi oleh diabetes, hipertensi, glomerulonephritis kronik, nefritis intersisial kronik, penyakit ginjal polikistik, obstruksi-infeksi saluran kemih, obesitas, dan komplikasi penyakit gagal ginjal kronis mempengaruhi hampir semua bagian tubuh manusia seperti hipertensi, anemia, penyakit kardiovaskuler (Infodatin, 2017).

Menurut World Health

Organization (2018) dalam Studi Global Burden of Diseases (GBD) tahun 2015 ada 1,2 juta pasien mengalami kematian dikarenakan gagal ginjal dan mengalami peningkatan $32 \%$ mulai tahun 2005. Pada tahun 2010 , kira-kira 2,3 juta hingga 7,7 juta pasien dengan penyakit ginjal stadium akhir telah meninggal dengan tidak melakukan dialisis, di samping itu, tiap tahunnya, kira-kira 1,7 juta pasien mengalami kematian sebab cedera ginjal akut secara keseluruhan. Oleh karena itu, diperkirakan ada 5-10 juta pasien meninggal tiap tahun disebabkan penyakit ginjal. Prevalensi penyakit ginjal kronis berdasarkan diagnosa dokter di Indonesia antara tahun 2013-2018 mengalami peningkatan dari $0,2 \%$ menjadi $0,38 \%$ (Couser, 2011). Sedangkan di Provinsi Riau prevalensi penyakit ginjal kronis 0,1\% (Riskesdas, 2013). Di RSUD Arifin Achmad Provinsi Riau dari tahun 20152020 ada 580 pasien CKD rawat inap dengan 652 kunjungan, dan dari tahun 2015-2020 ada 755 pasien CKD rawat jalan dengan 9.994 kunjungan (Rekam medik RSUD Arifin Achmad, 2020).

Menurut Muttaqin (2011) satu diantara tindakan terhadap pasien gagal ginjal kronis ialah dilakukannya hemodialiasis (HD). Hemodialisis ialah melakukan terapi yang mengganti ginjal yang terbanyak dilakukan dan mengalami peningkatan tahun demi tahun. Hemodialisis ialah sebuah proses yang dilakukan terhadap pasien dengan kondisi parah yang membutuhkan terapi dialysis berjangka pendek (beberapa hari atau minggu) atau penderita dengan penyakit ginjal tahap akhir atau End Stage Renal Diasease (ESRD) yang membutuhkan terapi berjangka panjang atau secarapermanen. Tujuan hemodialisis ialah mempertahankan hidup pasien yang memiliki tujuan meminimalisir kadar urea, kreatinin dan zat-zat toxic lain dalam darah, dan menggantikan fungsi kerja ginjal untuk proses ekskresi (produk sisa metabolisme pada tubuh, seperti urea, kreatinin, dan sisa hasil metabolisme lain). Fungsi lain misalnya pengganti fungsi ginjal untuk pengeluaran cairan tubuh yang dalam konsisi ginjal masih sehat cairan itu dikeluarkan dalam bentuk urine, peningkatan kualitas kehidupan pasien yang terjadi penurunan fungsi ginjal dan berfungsi sebagai pengganti fungsi ginjal sembari menantikan alternatif pengobatan lain (Suharyanto, 2013).

Pasien penyakit ginjal kronik memiliki risiko lebih besar menjadi sangat sakit karena COVID-19. Pasien penyakit ginjal kronik harus melakukan pencegahan dalam tiap harinya untuk jaga jarak diantara orang-orang ketika pergi ke luar rumah, jauhkan dari orang lain yang sedang sakit, membatasi kontak erat, cuci tangan atau menggunakan hand sanitizer sesering mungkin, hindari keramaian sebanyak mungkin, selama Covid-19 dan tetaplah untuk dirumah. Akan tetapi, penting untuk diketahui bahwa penderita ginjal diperlukan untuk perawatan dialisis lanjutan dengan jadwal teratur dan melakukan pencegahan yang dibutuhkan seperti yang diberikan rekomendasi oleh tim perawatan kesehatan mereka (National Kidney Foundation, 2020).

Penelitian Jang-hee et al (2020) menunjukan bahwa pasien pertama hemodialisis yang terkonfirmasi di Daegu total pasien hemodialisis dan 7 petugas kesehatan di 11 unit hemodialisis didiagnosis menderita Covid-19. Jumlah total pasien hemodialisis dan petugas 
kesehatan di 11 unit hemodialisis masing masing adalah 1.175 dan 278. Tingkat kejadian kasus yang terkonfirmasi di 11 unit hemodialisis adalah 0,9\% (11 dari 1.175) diantara pasien yang sedang melakukan hemodialisis dan $2,5 \%$ (7 dari 278) di antara petugas kesehatan. Sedangkan di Indonesia menunjukan bahwa $2,3 \%$ angka kematian penyakit penyerta Covid-19 adalah penyakit ginjal (KPCEN, 2020). Menurut Indonesian Renal Registry (2018) jumlah jumlah pasien hemodialisis di Indonesia sejumlah 198.575 penderita dengan total tindakan HD sejumlah 2.754.409 kali.

Peneliti melakukan studi pendahuluan pada hari senin 14 September 2020 di ruang hemodialisis RSUD Arifin Achmad. Peneliti melakukan wawancara terhadap 5 orang pasien hemodialisys. Dari hasil wawancara didapatkan 5 pasien mengatakan hemodialisis sudah menjadi kebutuhan hidup pasien walaupun pasien menjalani hemodialisis pada saat pandemi. Pasien sulit untuk menjaga jarak, dan ketika berpergian pasien mengatakan jarang untuk menggunakan dan membawa hand sanitizer saat berpergian, peneliti juga melakukan observasi bahwa masih ada pasien dan keluarga pasien yang masuk dan keluar ruang hemodialisis tanpa menggunakan handsanitizer yang sudah disediakan oleh rumah sakit, dan beberapa dari keluarga pasien ada yang menggunakan masker dengan kurang tepat. Berdasarkan penjelasaan diatas peneliti memiliki ketertarikan untuk melaksanakan penelitian untuk mengetahui "Gambaran Tindakan Pencegahan Penularan Covid-19 Pada Pasien Hemodialisis Di Rsud Arifin Achmad Provinsi Riau?". Tujuan penelitian ini adalah untuk mengetahui tindakan pencegahan penularan covid-19 pada pasien hemodialisis.

\section{METODE PENELITIAN}

Desain pada penelitian ini ialah metode deskriptif dengan jenis penelitian kuantitatif dengan Jumlah sampelnya yang diperlukan yakni 43 pasien, adapun kriteria inklusi bersedia dijadikan respondennya dan pasien yang menjalani hemodialisis, Penelitian ini memakai teknik Consecutive Sampling. Teknik tersebut berjenis non probability yang terbaik serta mudah dilaksanakan. Pengumpulan datanya dilaksanakan melalui mengamati tindakan responden dalam kepada responden dan meminta responden mengisi kuesioner identitas pasien dan akan melihat atau mengobservasi dan menceklis angket yang telah disediakan sampai selesai. Dikarenakan peneliti kesulitan untuk mengobservasi dua ruangan sekaligus yakni ruang hemodialisis dan ruang tunggu maka peneliti menggunakan asissten yang sudah dilakukan persamaan persepsi sebelumnya untuk membantu peneliti melakukan observasi.

\section{HASIL DAN PEMBAHASAN}

Berdasarkan hasil penelitian di dapatkan hasil sebagai berikut :

\section{Tabel 1 Distribusi Frekuensi Responden \\ Berdasarkan Karakteristik Usia, Jenis Kelamin, Pendidikan dan Riwayat Penyakit Terdahulu $n=(43)$}

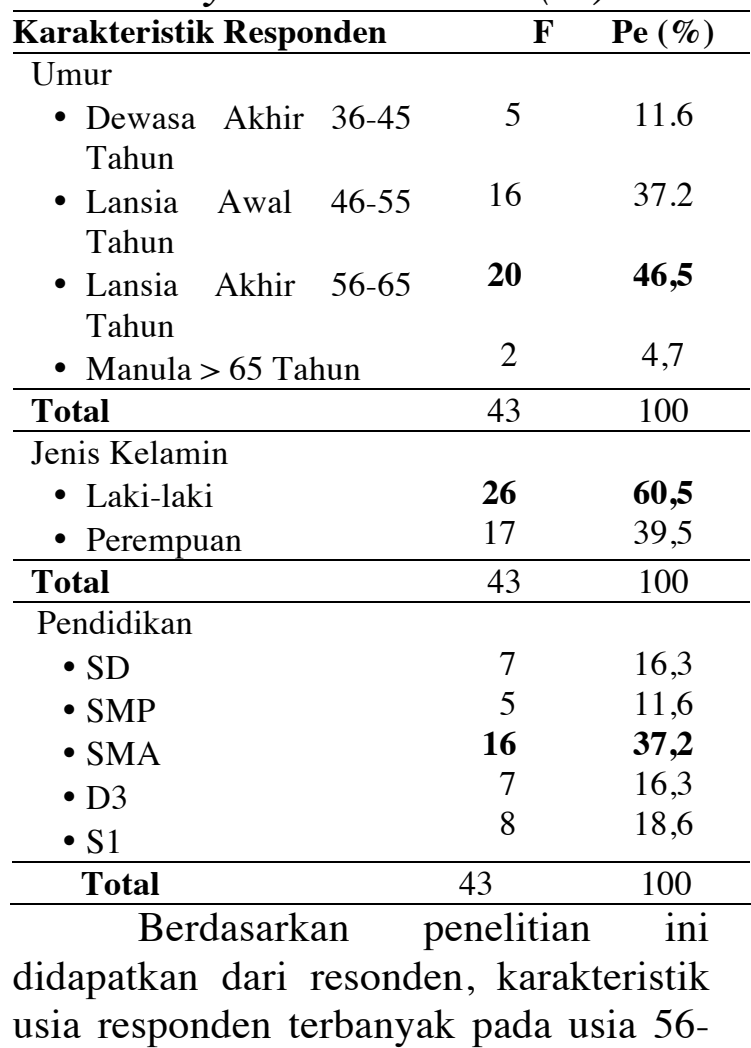


65 tahun (46,5\%). Penelitian oleh Chang dalam Tjekyan (2014) di Taiwan memberi laporan prevalensi penyakit gagal ginjal kronik di usia $>75$ tahun $17-$ 25 kali lebih banyak dibanding usia $<20$ tahun. Sedangkan hasil penelitian Pranandari (2015) mengatakan pasien yang berusia $>60$ tahun memiliki $2,2 \%$ kali lebih banyak terkena gagal ginjal kronik dibanding pasien yang usianya $<60$ tahun. Penyebabnya semakin usianya bertambah, maka fungsi ginjalnya mengalami penurunan. Hal ini berkaitan dengan turunnya kecepatan eksresi glomerulus serta fungsi tubulusnya memburuk. Hal ini diperkuat oleh penelitian Delima (2017) yang mengatakan semakin bertambahnya usia semakin pula beresiko untuk mengalami penyakit ginjal kronik, dimana pada penelitian ini usia 61-86 tahun mempunyai risiko 4,51\% kali mengidap penyakit ginjal kronik dibanding yang usianya 18-30 tahun.Jenis Kelamin

Menurut peneliti peningkatan usia dapat meningkatkan resiko penurunan fungsi ginjal dan penurunan sistem kekebalan tubuh sehingga lansia juga rentan atau lebih beresiko tekena paparan virus corona dan diperparah dengan pola hidup yang tidak teratur dan tindakan pencegahan kurang optimal. Hal tersebut sesuai penelitian Hadumaon (2020) mengakatan lansia tergolong pada kelompok yang mempunyai risiko tinggi terinfeksi Virus Corona karena melemahnya sistem kekebalan tubuh sebab pertambahan usianya.

Menurut Syarifah (2020) para laki-laki merupakan kelompok yang risikonya tinggi terjangkit Virus Corona oleh peneliti China, USA, serta WHO. Berdasar pada data pasien yang menjalani perawatan di Kota Wuhan memperlihatkan mayoritasnya para pria yang terjangkit COVID-19. Chinese Center for Disease Control and Prevention mengatakan pria yang terjangkit COVID-19 mempunyai risiko meninggal 2 kali lebih tinggi dibanding wanita. Hal tersebut terbuktikan di Italia di mana tingkat kematian pria lebih tinggi daripada wanita Menurut peneliti jenis kelamin termasuk mempengaruhi bentuk tindakan serta kualitas hidup yang kurang baik seperti merokok, hal ini di perkuat oleh penelitian Astrini (2013) sebab secara klinik pria mempunyai risiko lebih tinggi terjangkit CKD (Chronic Kidney Disease) dibanding wanita. Kecenderungan tersebut mungkin terjadi sebab faktor gaya hidup misal mengonsumsi alcohol serta merokok yang umumnya dilaksanakan oleh pria, dan penelitian dari Tarigan (2020).

Kelompok yang mempunyai risiko tinggi terjangkit Virus Corona ialah penghisap vape serta perokok yang dikatakan peneliti Jerman dan Indonesia. Sesuai penjelasan Feni Fitriani, seorang dokter spesialis Paru dari Indonesia yakni penghisap vape serta perokok telah rentan pada saluran pernapasannya, oleh karenanya mudah terjangkit Virus Corona. Pernyataannya dikuatkan oleh Amin Soebandrio, Kepala Lembaga Biologi dan pendidikan Tinggi Eijkman bahwa merokok bisa mengubah sel paru seseorang menjadi lebih rentan terjangkit SARS-COV2 dengan meningkatnya reseptor yakni molekul ACE2.

Tabel 2 Distribusi Frekuensi Responden Berdasarkan Kategori Dari Tindakan Pencegahan Penularan Covid-19 Pada Pasien Hemodialysis

\begin{tabular}{llll}
\hline Indikator & Karakteristik & $\mathrm{F}$ & $(\%)$ \\
\hline Mengecek & Baik & 43 & 100 \\
\cline { 2 - 4 } Suhu & Buruk & 0 & 0 \\
\hline $\begin{array}{l}\text { Menggunakan } \\
\text { Masker }\end{array}$ & Baik & 31 & 74,4 \\
\cline { 2 - 4 } $\begin{array}{l}\text { Mencuci } \\
\text { Tangan }\end{array}$ & Buruk & 11 & 25,6 \\
\cline { 2 - 4 } $\begin{array}{l}\text { Menjaga } \\
\text { Jarak }\end{array}$ & Buruk & 26 & 60,5 \\
\hline $\begin{array}{l}\text { Menerapkan } \\
\text { Etika Batuk } \\
\text { dan Bersin }\end{array}$ & Baik & 30 & 39,4 \\
\cline { 2 - 4 } & Buruk & 13 & 30,2 \\
\hline $\begin{array}{l}\text { Tidak } \\
\text { Menyentuh } \\
\text { Mata, Hidung }\end{array}$ & Buruk & 35 & 81,4 \\
\cline { 2 - 4 } & Buruk & 8 & 18,6 \\
\hline
\end{tabular}




\begin{tabular}{l}
\hline dan Mulut \\
\hline Total \\
Berdasarkan penelieitan ini \\
didapatkan bahwa tindakan pencegahan \\
yang di teliti dari mencek suhu dari 43 \\
responden adalah "Baik" yakni (100\%). \\
Menurut peneliti mengecek suhu atau \\
mengskrining adalah langkah awal \\
pendekteksi covid-19 di pintu masuk \\
rumah sakit. menurut KEMENKES (2020) \\
Skrining merupakan proses penapisan \\
pasien di mana seorang individu dievaluasi \\
dan disaring menggunakan kriteria gejala \\
dan riwayat epidemiologis, untuk \\
menentukan pasien tersebut masuk ke \\
dalam kategori dicurigai covid-19 atau \\
bukan, demam (suhu badan $>38$ C C) atau \\
riwayat demam dan gejala gangguan \\
pernafasan (batuk, sesak nafas, nyeri \\
tenggorokan) merupakan salah satu gejala \\
covid-19.
\end{tabular}

Hasil dari tindakan pencegahan covid-yang diteliti dari menggunkan masker dari 26 responden $(74,4 \%)$. Hal ini sejalan dengan teori bahwa penyebaran covid-19 melalui droplet yang keluar dari batuk atau bersin dari hidung atau mulut maka dari itu dianjurkan untuk selau memakai masker, mencuci tangan, menghindari keramaian dan menjauhi keramaian (Kemenkes RI, 2020). Hasil penelitian menunjukan dari 26 responden $(60,5 \%)$ melakukan tindakan pencegahan penularan covid-19 dengan mencuci tangan.

Hal ini sejalan dengan teori bahwa mencuci tangan dengan sabun atau handsanitizer sampai bersih selain dapat membunuh virus yang mungkin ada ditangan, tindakan ini juga merupakan salah satu tindakan yang mudah dan murah. Sekitar $98 \%$ penyebaran penyakit bersumber dari tangan. Karena itu, menjaga kebersihan tangan adalah hal yang sangat penting (Kemenkes RI, 2020).

Hasil penelitian dari 30 responden $(69,5 \%)$ melakukan tindakan pencegahan penularan covid-19 dengan menjaga jarak minimal 1,5 meter, Hal ini sejalan dengan teori ketika sesorang batuk atau bersin, maka mereka menyemprotkan tetesan cairan kecil (droplate) dari hidung atau mulut seseorang yang mungkin mengandung virus, jika terlalu dekat maka bisa menghirup tetesan air, termasuk virus covid-19 jika orang tersebut pembawa virus tersebut (Kemenkes, RI, 2020).

Mayoritas dari 35 responden $(81,4 \%)$ melakukan tindakan pencegahan penularan covid-19 dengan etika batuk dan bersin. Hal ini sejalan dengan teori bahwa etika batuk merupakan tata cara batuk yang baik dan benar, dengan cara menutup hidung dan mulut dengan tissue atau lengan baju sehingga bakteri dan virus tidak menyebar ke udara dan tidak menular ke orang lain. Tujuan utama menjaga etika batuk adalah mencegah penyebaran suatu penyakit secara luas melalui udara bebas (Droplets) dan membuat kenyamanan pada orang di sekitarnya. Droplets tersebut dapat mengandung kuman infeksius yang berpotensi menular ke orang lain disekitarnya melalui udara pernafasan. (Dinkes padang, 2020).

Mayoritas dari 35 responden (81, 4\%) melakukan tindakan pencegahan penularan covid-19 dengan tidak menyentuh mata, hidung dan mulut. Hal ini sejalan dengan teori bahwa tangan banyak menyentuh permukaan dan dapat terkontaminasi dengan virus. Setelah terkontaminasi, tangan dapat memindahkan virus tersebut ke mata, hidung, dan mulut. Dari mata, hidung dan mulut tersebut virus bisa masuk ke tubuh dan dapat menyebabkan sakit (Pramana, 2020)

\section{Tabel 3 Distribusi Frekuensi Responden Berdasarkan Kategori Dari Tindakan}

\begin{tabular}{lcc}
\multicolumn{1}{c}{$(\mathbf{4 3 )}$} & & \\
\hline Karakteristik & F & $(\boldsymbol{\%})$ \\
\hline Baik & $\mathbf{2 7}$ & $\mathbf{6 2 , 8}$ \\
Buruk & 16 & 37,2 \\
\hline Total & $\mathbf{4 3}$ & $\mathbf{1 0 0}$ \\
\hline
\end{tabular}




\section{Gambaran Tindakan Pencegahan Penularan Covid-19 pada Pasien Hemodialisis}

Berdasarkan penelitian ini didapatkan hasil responden yang diteliti dari tindakan pencegahan penularan covid19 pada pasien hemodialisis hasil observasi dari 43 responden adalah "Baik" yakni $(62,8 \%)$ dan "Buruk" yakni $(37,2 \%)$. Hal ini sejalan dengan penelitian dari Utami, Mose, dan Martini (2020) penelitian keterampilan, sikap serta pengetahuan masyarakat dalam mencegah Covid-19 di DKI Jakarta menunjukkan keterampilan masyarakat dalam mencegah covid-19 yakni "Baik" (70,3\%). Keterampilan tersebut ialah tindakan respondennya atas protokol new normal misal konsistensinya memakai masker, tetap di rumah, selalu cuci tangan memakai sabun pada air mengalir, selalu sedia disinfektan, segera mandi sesudah keluar dari rumahnya, tidak berkontak fisik, jaga jarak, membatasi jumlah penumpang di kendaraannya, menjaga sistem kekebalan tubuhnya dengan nutrisi yang adekuat serta rutin berolahraga.

Menurut Perry \& Potter (2015) tindakan mencegah penularan penyakit ialah aspek terpenting selama menjalani kehidupan yang sehat. Tindakan pencegahan dengan memanfaatkan kegiatan peningkatan kesehatan khusus, dimana hal ini dibuat supaya membantu responden menurunkan risiko sakitnya, mempertahakan fungsi secara optimal, serta meningkatkan pembiasaan terkait kesehatan yang baik. Upaya pencegahan yang dilaksanakan responden guna mencegah Covid-19 sudah baik seperti, menggunakan masker, tidak berkumpul, menjaga jarak, mencuci tangan serta tidak bersalaman.

\section{KESIMPULAN}

Merujuk kepada hasil dari penelitian memperlihatkan karakteristik responden paling banyak berada direntang usia lansia akhir 56-65 tahun dimana jumlah respondennya $20 \quad(46,5 \%)$. Umumnya respondennya berjenis kelamin laki-laki yang jumlahnya $26(60,5 \%)$, dari data pendidikan responden didapatkan 16 $(37,2 \%)$ responden tamatan SMA. Penelitian menunjukKan bahwa hasil dari gambaran tindakan pencegahan penularan covid-19 pada pasien hemodialisis adalah "Baik" sebanyak 27 (62,8\%) responden.

\section{UCAPAN TERIMAKASIH}

Penulis mengucapkan terimakasih untuk semua pihak yang telah membantu peneliti dalam membuat artikel penelitian ini.

\section{DAFTAR PUSTAKA}

Cipta, P. (2020). Langkah-langkah perlindungan dasar terhadap coronavirus baru (covid-19). https://www.researchgate.net/publicati on/340443622_Langkahlangkah_Perlindungan_Dasar_Terhad ap_Coronavirus_baru_Covid-19

Couser, W.G., Remuzzi, G., Mendis, S., \& Tonelli, M. (2011). The contribution of chronic kidney disease to the global burden of major noncommunicable diseases.

https://pubmed.ncbi.nlm.nih.gov/2199 $3585 /$.

Covid Riau. (2020). Grafik data suspek covid-19 provinsi riau. https://corona.riau.go.id/grafik/.

Delima. (2017). Faktor Risiko Penyakit Ginjal Kronik. Studi Kasus Kontrol di Empat Rumah Sakit di Jakarta Tahun 2014.

http://dx.doi.org/10.22435/bpk.v45i1 . 7328.17-26

Fathiyah. (2020). Pedoman kesiapsiagaan menghadapi infeksi novel coronavirus (2019-ncov).

https://www.kemkes.go.id/resources/d ownload/info-terkini/Coronavirus/DO KUMEN_RESMI_Pedoman_Kesiapsi agaan_nCoV_Indonesia_28\%20Jan\% 202020.pdf 
Hadumaon, S. T. (2020). Mencari kelompok berisiko tinggi terinfeksi virus corona dengan discourse network analysis. https://jurnal.ugm.ac.id/jkki/article/vie w/55475

Huang, A. (2020). Clinical features of patients infected with 2019 novel coronavirus in Wuhan, China. https://www.thelancet.com/pdfs/journ als/lancet/PIIS0140-

6736\%2820\%2930183-5.pdf

Indonesia Renal Registry. (2018). Report of indonesian renal registry. https://www.indonesianrenalregistry.o $\mathrm{rg} / \mathrm{data} / \mathrm{IRR} \% 202018 . \mathrm{pdf}$

Infodatin Ginjal. (2017). Situasi penyakit ginjal kronis.

https://www.kemkes.go.id/resources/down load/pusdatin/infodatin/infodatin $\% 20 \mathrm{~g}$ injal\%202017.pdf.

Jang-Hee, C. (2020). Hemodialysis with cohort isolation to prevent secondary transmission during a Covid-19 outbreak in korea. https://www.ene.gr/DOCUMENTS/20 20/BIBLIOGRAPHY/4.pdf

Kementerian Kesehatan. (2020). 13,2 persen pasien covid-19 yang meninggal memiliki penyakit hipertensi.

https://www.kemkes.go.id/article/print /20101400002/13-2-persen-pasiencovid-19-yang-meninggal-memilikipenyakit-hipertensi.html

Kemenenterian Kesehatan. (2020). Pedoman apa yang harus dilakukan cegah Covid19. https://promkes.kemkes.go.id/panduan -pencegahan-penularan-covid-19untuk-masyarakat

Komite Penanganan Covid-19 dan Pemulihan Ekonomi Nasional. (2020). Peta sebaran Covid-19.

https://covid19.go.id/peta-sebaran-covid19 PERNEFRI. (2020). Panduan pencegahan transmisi covid-19 di unit hemodialisis. http://pernefri.org/acara/webinar\%20 All.pdf
PERNEFRI. (2014). 7th report of indonesia renal registry.

Potter, P.A., \& Perry, A.G. (2010). Buku ajar fundamental keperawatan. Jakarta: Salemba Medika

National Kidney Foundation. (2020). Kidney disease \& covid-19. https://www.kidney.org/coronavirus/ki dney-disease-covid-19

Nuari, A. N., \& Widayati, D. (2017). Gangguan pada sistem perkemihan \& penatalaksanaan keperawatan. Deepublish: Yogyakarta.

Pranandari, R. (2015). Faktor risiko gagal ginjal kronik di unit hemodialisis Rsud Wates Kulon Progo. https://jurnal.ugm.ac.id/majalahfarmas eutik/article/view/24120

Riskesdas. (2018). Badan penelitian dan pengembangan kesehatan kementrian kesehatan ri.

https://www.kemkes.go.id/resources/down load/general/Hasil\%20Riskesdas $\% 202$ 013.pdf.

Saryono. (2010). Metodologi penelitian kesehatan. Mitra Cendikia Press: Jogjakarta

Surharyanto, T., \& Madjid, A. (2014). Asuhan keperawatan pada klien dengan gangguan sistem perkemihan. CV. Trans Info Media: Jakarta Timur

Syarifah, F. (2020). Alasan pria lebih rentan terinfeksi dan meninggal karena Covid-19. Liputan6.com.

https://www.liputan6.com/health/read/422 0728/alasanpria-lebih-rentanterinfeksi-dan meninggalkarenacovid-19

Tarigan, M. (2020). Awas, perokok lebih rentan terkena virus corona. https://gaya.tempo.co/read/1319325/ awas-perokok-lebih-rentan-terkenaviruscorona/full\&view $=$ ok

Utami, R.A., Mose, R.E., \& Martini, M. (2020). Pengetahuan, sikap dan keterampilan masyarakat dalam pencegahan covid-19 di DKI Jakarta. https://www.researchgate.net/publicati on/343307853_Pengetahuan_Sikap_d an_Keterampilan_Masyarakat_dalam_ 
Pencegahan_COVID-

19_di_DKI_Jakarta

World Health Organization (WHO). The global burden of kidney disease and the sustainable development goals. https://www.who.int/bulletin/volumes/ 96/6/17-206441/en/.

World Health Organization (WHO). Who coronavirus (covid-19) dashboard (2020). https://covid19.who.int/

Yuliana. (2020). Wellness and healthy magazine,corona viru diseases (covid19). Fakultas kedokteran universitas $L$ ampung. https://wellness.journalpress .id/wellness/article/download/21026/p df. 